http://dx.doi.org/10.5800/GT-2012-3-3-0071

\title{
PRESENT-DAY STRESS STATE OF THE SHANXI TECTONIC BELT
}

\author{
Kaiying Wang ${ }^{1}$, Jin $\mathrm{Ma}^{1}$, Guiling Diao ${ }^{2}$ \\ ${ }^{1}$ State Key Laboratory of Earthquake Dynamics, Institute of Geology, China Earthquake Administration, \\ Beijing, China \\ ${ }^{2}$ Earthquake Administration of Hebei Province, Shijiazhuang, China
}

\begin{abstract}
The Shanxi tectonic belt is a historically earthquake-abundant area. For the majority of strong earthquakes in this area, the distribution of earthquake foci was controlled by the N-S oriented local structures on the tectonic belt. Studies of the present stress state of the Shanxi tectonic belt can contribute to the understanding of the relationship between strong earthquakes' occurrence and their structural distribution and also facilitate assessments of regional seismic danger and determination of the regions wherein strong earthquakes may occur in future. Using the Cataclastic Analysis Method (CAM), we performed stress inversion based on the focal mechanism data of earthquakes which took place in the Shanxi tectonic belt from 1967 to 2010. Our results show that orientations of the maximum principal compressive stress axis of the Shanxi tectonic belt might have been variable before and after the 2001 Kunlun $M_{S}=8.1$ strong earthquake, with two different superior trends of the NW-SE and NE-SW orientation in different periods. When the maximum principal compressive stress axis is oriented in the NE-SW direction, the pattern of the space distribution of the seismic events in the Shanxi tectonic belt shows a trend of their concentration in the N-S oriented tectonic segments. At the same time, the stress state is registered as horizontal shearing and horizontal extension in the $\mathrm{N}-\mathrm{S}$ and NE-SW oriented local segments in turn. When the maximum principal compressive stress axis is NW-SE oriented, the stress state of the N-S and NE-SW oriented tectonic segments is primarily registered as horizontal shearing. Estimations of plunges of stress axes show that seismicity in the Shanxi belt corresponds primarily to the activity of low-angle faults, and high-angle stress sites are located in the NE-SW oriented extensional tectonic segments of the Shanxi belt. This indicates that the stress change of the Shanxi belt is caused by adjustment of the regional stress field, rather than by the diverse seismic activities.
\end{abstract}

Key words: Shanxi tectonic belt, stress state, the 2001 Kunlun $M_{\mathrm{S}}=8.1$ earthquake.

Recommended by V.A. San’kov 20 August 2012

Citation: Wang K., Ma J., Diao G., 2012. Present-day stress state of the Shanxi tectonic belt. Geodynamics \& Tectonophysics 3 (3), 195-202. doi:10.5800/GT-2012-3-3-0071.

\section{СОВРЕМЕННОЕ НАПРЯЖЕННОЕ СОСТОЯНИЕ ТЕКТОНИЧЕСКОГО ПОЯСА ШАНЬСИ}

\author{
Ван Кайюин ${ }^{1}$, Ма Дзинь ${ }^{1}$, Дао Джилин ${ }^{2}$ \\ ${ }^{1}$ Государственная центральная лаборатория геодинамики Земли, Институт геологии, Администрация \\ по землетрясениям Китая, Пекин, Китай \\ ${ }^{2}$ Администрация по землетрясениям провинции Хэбэй, Шицзячжуан, Китай
}

Аннотация: Согласно историческим данным, тектонический пояс Шаньси выделяется как зона с многочисленными землетрясениями. В большинстве случаев распределение эпицентров землетрясений контролируется локальными меридиональными структурами, входящими в состав данного тектонического пояса. Изучение современного напря- 
женного состояния тектонического пояса Шаньси вносит вклад в понимание взаимоотношений между проявлением сильных землетрясений и их структурным распределением, а также содействует оценке региональной сейсмической опасности и выделению регионов, где в будущем возможны сильные землетрясения. С применением метода катакластического анализа (Cataclastic Analysis Method, CAM) проведена реконструкция напряженного состояния на базе данных о механизмах очагов землетрясений, зарегистрированных в тектоническом поясе Шаньси с 1967 г. по 2010 г. Результаты исследования показали, что ориентации осей максимальных главных напряжений сжатия в тектоническом поясе Шаньси, возможно, подвергались изменениям как до, так и после сильного Куньлунского землетрясения $\left(M_{\mathrm{S}}=8.1\right)$, произошедшего в 2001 г., при этом в разные временные периоды выделены два разных тренда - северо-западной и северо-восточной ориентации. При ориентации оси максимального главного напряжения сжатия в северовосточном направлении на схеме пространственного распределения сейсмических событий в тектоническом поясе Шаньси видна тенденция концентрации землетрясений в тектонических сегментах, ориентированных в меридиональном направлении. При этом зарегистрированное напряженное состояние характеризуется горизонтальным сдвигом и горизонтальным растяжением локальных сегментов, ориентированных в меридиональном и северо-восточном направлении. При ориентации оси максимального главного напряжения сжатия в северо-западном направлении напряженное состояние на тектонических сегментах, ориентированных в меридиональном и северо-восточном направлении, в основном определяется как горизонтальный сдвиг. Оценка углов погружения осей напряжений показывает, что сейсмичность тектонического пояса Шаньси коррелирует главным образом с активностью пологих разломов, при этом участки разломов с большими углами наклонов осей напряжений располагаются в северо-восточных тектонических сегментах пояса, подверженных растяжению. Результаты исследований показывают, что современное напряженное состояние тектонического пояса Шаньси изменяется в связи с вариациями регионального поля напряжений.

Ключевые слова: тектонический пояс Шаньси, состояние напряжения, Куньлунское землетрясение $\left(M_{\mathrm{S}}=8.1\right)$.

\section{INTRODUCTION}

Located at the eastern edge of the Ordos block, the Shanxi tectonic belt is an active tectonic structure that evolved in the late Cenozoic. It consists of five large fault basins spreading left-laterally and surrounded by the NESW and nearly N-S oriented faults at the edges. The basins are S-shaped in plane. The Shanxi tectonic belt is an active belt of strong earthquakes in the Eastern China. According to the available records, seven strong earthquakes with magnitudes above 7.0 have occurred in the belt: $M s=7 \frac{1}{2}$ in 512 at the northern piedmont of the Wutai mountain, $M s=71 / 4$ in 1038 in the piedmont zone of the Xizhou mountain, $M s=7.0$ in 1683 in the piedmont zone of the Yunzhong mountain, Ms=7.0 in 1626 in the piedmont zone of the Taibaiwei mountain, $M s=8.0$ in 1303 in the piedmont zone of the Dayang-Huoshan mountain, $M s=71 / 2$ in 1695 and $M s=71 / 2$ in 1679 at the Linfen-Fushan fault. As shown by the distribution of epicenters of the historical strong earthquakes, six earthquakes occurred in the $\mathrm{N}-\mathrm{S}$ oriented segments or at the turning area from the N-S oriented structure to the NE-SW oriented one in the Shanxi tectonic belt. The only exception is the earthquake in the piedmont fault zone of the Taibaiwei mountain (Fig. 1). This suggests that the occurrence of strong earthquakes is controlled by the N-S oriented segments of the Shanxi tectonic belt. This important phenomenon and its dynamic implications highly deserve to be studied in detail.

For a very long time, there have been a lot of disputes over studies of the recent movements of the Ordos block where the Shanxi tectonic belt is located. For example, the present motion state of the Ordos block was regarded as counterclockwise rotation [Su, 1984; Shao, Su, 1999], upward movement [Hu, 1988; Deng et al., 1999], clockwise rotation [Zhang et al., 2002] or clockwise rotation overlayed by counterclockwise rotation [Xu et al., 1994; Chen et al., 2005] and alternating activity between clockwise rotation and counterclockwise rotation [Fan et al., 2003]. One of the reasons for many disputes over the present motion state of the Ordos block is the current complicated stress state of the Ordos block. The distribution of the current crustal stress axes [Ma, 1989] is revealed from in-situ stress measurements, data on focal mechanism and crustal deformation measurements. The distribution of the principal compressive stress axes of the western and eastern boundary of the Ordos block shows that NE-SW orientation and NW-SE orientation coexists, reflecting the complexity of the stress state of the Ordos block.

In this paper, we propose to perform stress analyses with regard to different time periods and tectonic segments with two different orientations in the Shanxi belt in order to reveal the causes of complexity of the stress state and the distribution of the historical strong earthquakes in the region under study.

\section{INVERSION OF THE PRESENT STRESS STATE OF THE SHANXI TECTONIC BELT}

By processing the database on 2000 focal mechanisms of earthquakes above $M s=1.0$ which occurred in the Shanxi tectonic belt from 1967 to 2010 (Fig. 2) and using 


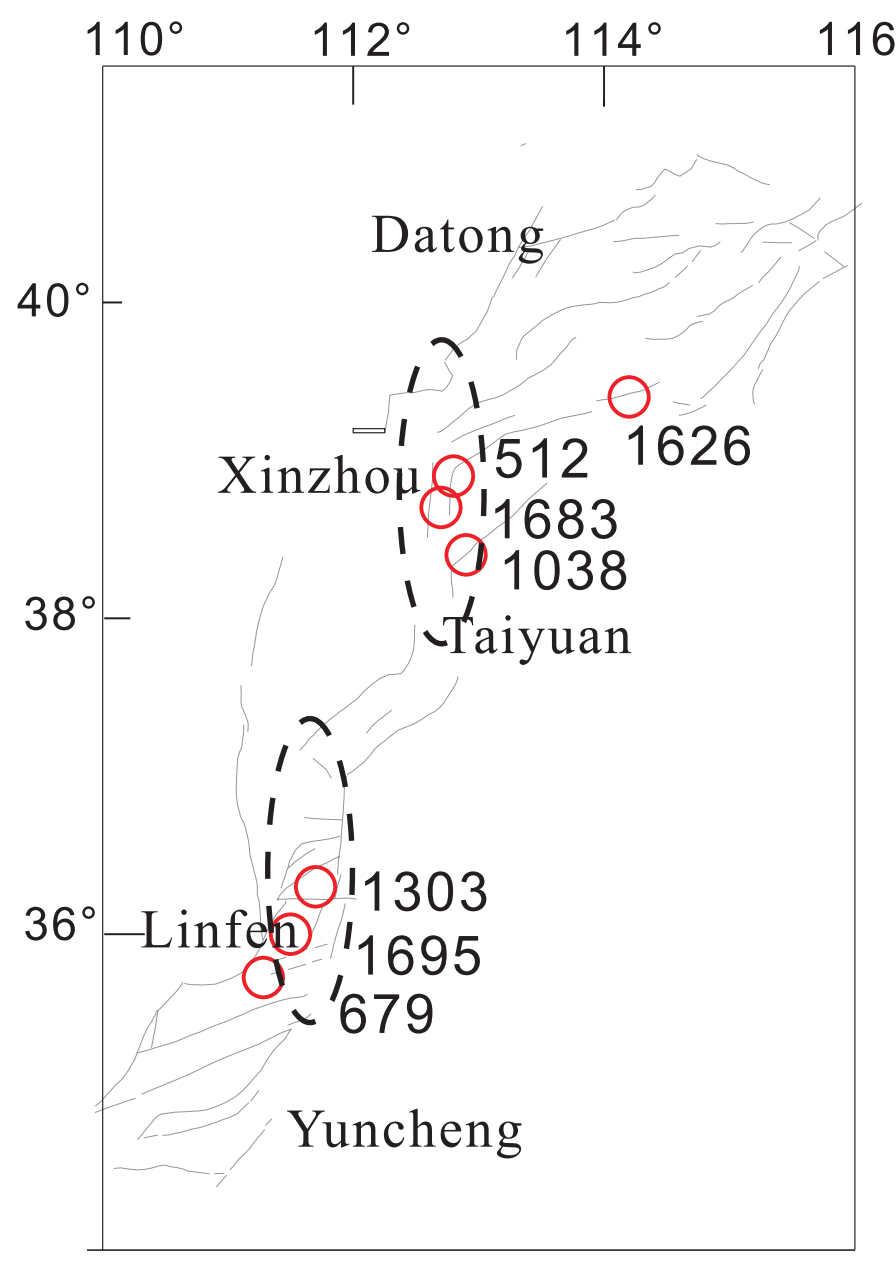

Fig. 1. Distribution of epicenters of historical strong earthquakes above 7.0 in the Shanxi tectonic belt. The $\mathrm{N}-\mathrm{S}$ trending segments are shown by ellipses.

Рис. 1. Распределение эпицентров по историческим данным о сильных землетрясениях (>7.0), произошедших в тектоническом поясе Шаньси (Китай). Участки, ориентированные в меридиональном направлении, показаны эллипсами.

the Cataclastic Analysis Method (hereafter referred to as CAM) [Rebetsky, 1999, 2003], we have calculated stress parameters to study the present-day stress state of the Shanxi belt.

In October 1989, four earthquakes above $M s=5.0$ occurred near Datong, Shanxi province within a short time period. Recently, several strong earthquakes took place in West China, including the $1996 \mathrm{Ms}=7.0$ Lijiang earthquake, the $2001 \mathrm{Ms}=8.1$ Kunlun earthquake, the 2008 $M s=8.0$ Wehchuan earthquake etc. We compiled the focal mechanism database and reviewed the events in their chronological sequence in order to conduct the stress analysis. If the occurrence of these strong earthquakes is a signal of adjustment of the stress field, the analysis results can be presented with breakdown by time periods. Figure 3 illustrates distributions of the maximum principal stress axes in the periods from January 1967 to September 1989, from October 1989 to February 1996 before the Lijiang earth- quake, from 1996 after the Lijiang earthquake to November 2001 before the Kunlun earthquake, from 2001 after the Kunlun earthquake to May 2008 before the Wenchuan earthquake and from 2008 after the Wenchuan earthquake to September 2010 etc. It is obvious that after the 2001 Kunlun earthquake, the maximum principal compressive stress axes of the Shanxi tectonic belt are mainly NE-SW oriented, whereas the data analysis from 1967 to 2001 before the Kunlun earthquake with breakdown by different periods of time show that the maximum principal compressive stress axes of the Shanxi tectonic belt are mainly NW-SE oriented. The stress state distribution in different time periods (Fig. 4) shows that the stress state is mainly horizontal shear in the time periods when the maximum principle compressive stress axes of the Shanxi tectonic belt are mainly NW-SE oriented. The maximum principal

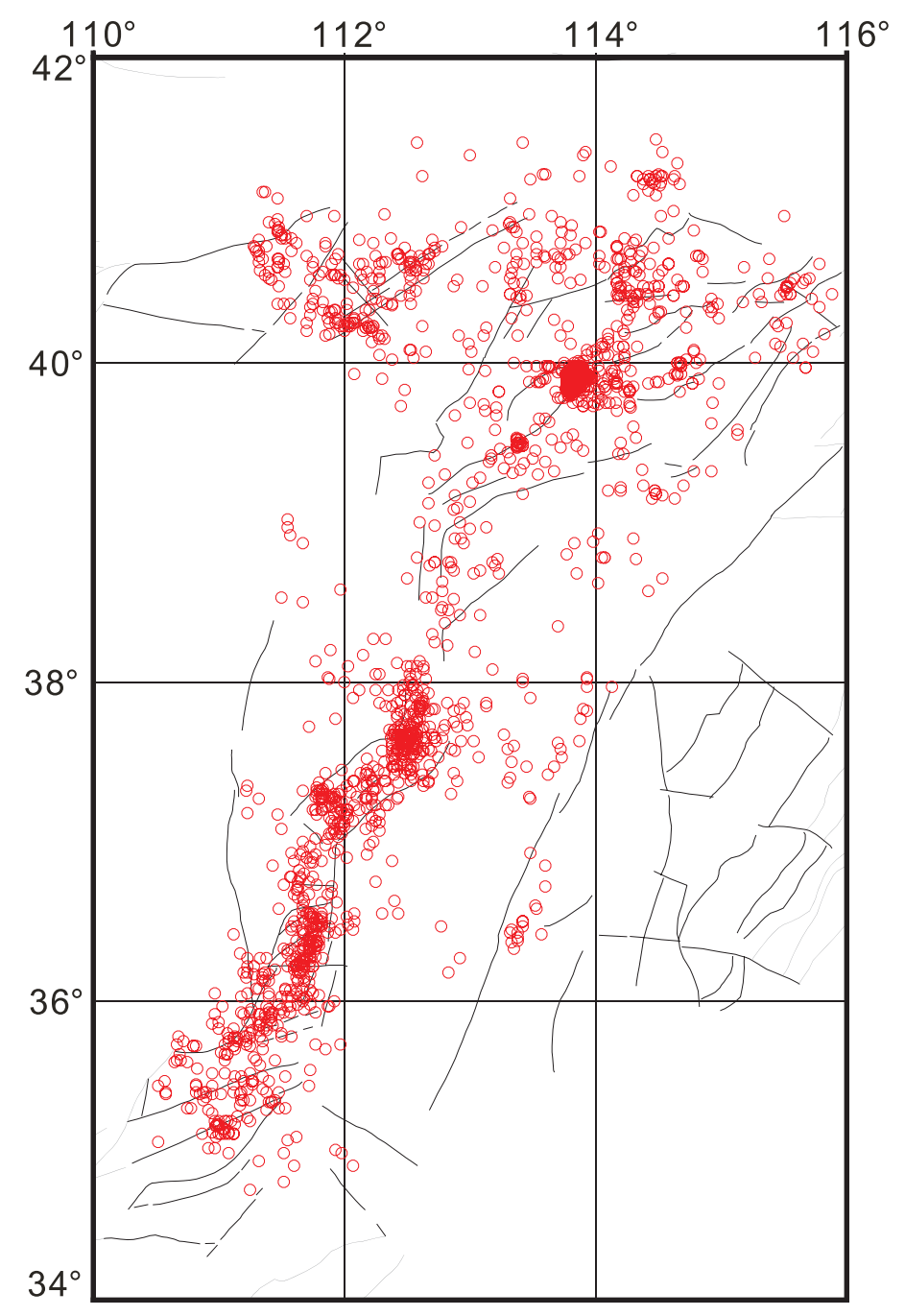

Fig. 2. Distribution of active faults in the Shanxi tectonic belt in China, and the earthquake epicenters according to the focal mechanism data.

Рис. 2. Распространение активных разломов в тектоническом поясе Шаньси (Китай) и эпицентры землетрясений с установленными механизмами очагов. 


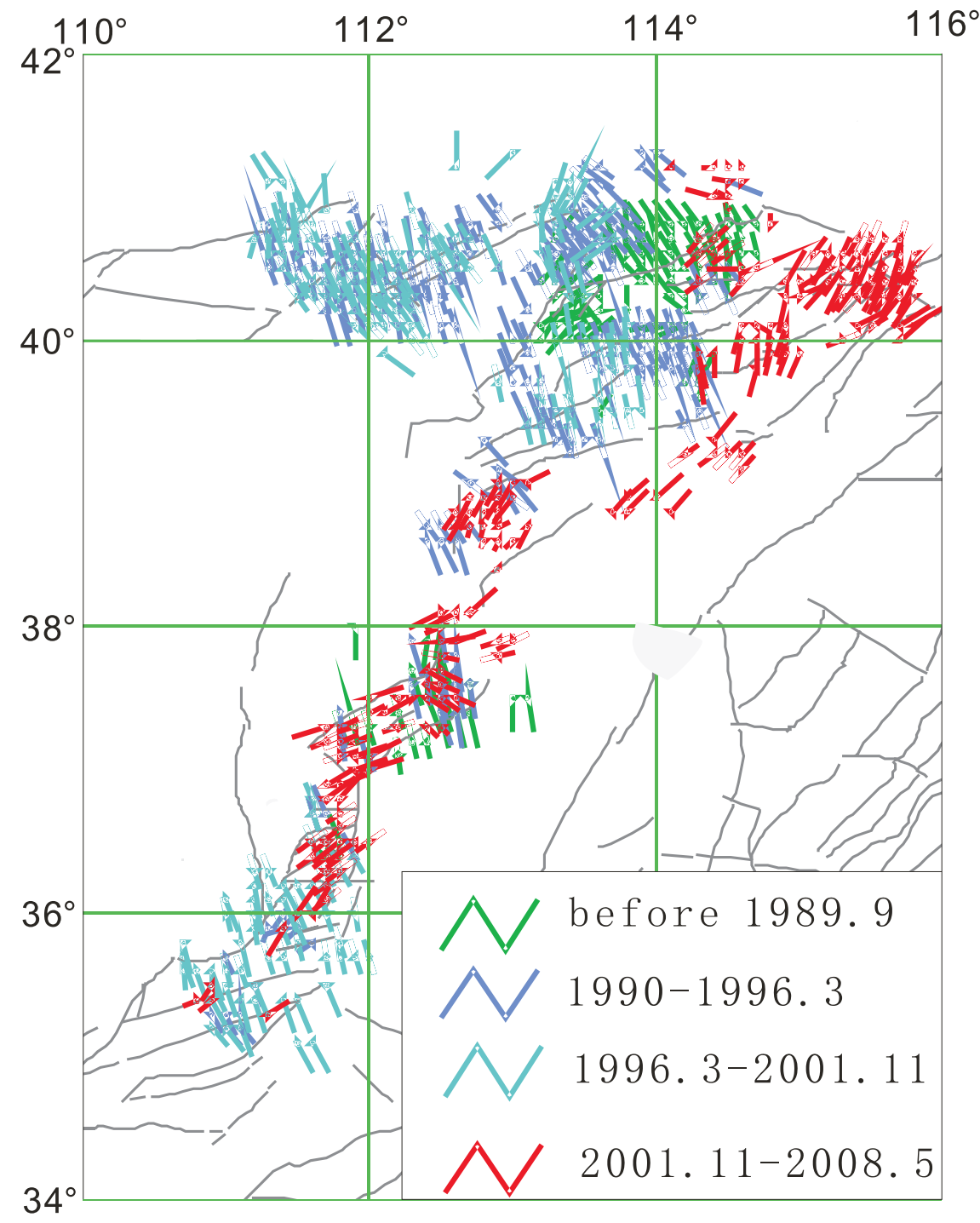

Fig. 3. Distribution of the maximum principal compressive stress axes of the Shanxi tectonic belt in the following periods of time: from 1967 to September 1989, from 1990 to 1996 before the Lijiang earthquake, from 1996 after the Lijiang earthquake to 2001 before the Kunlun earthquake, and from 2001 after the Kunlun earthquake to 2008 before the Wenchuan earthquake.

Рис. 3. Распределение осей максимальных главных напряжений сжатия в тектоническом поясе Шаньси в следующие временные периоды: с 1967 г. по сентябрь 1989 г., с 1990 г. по 1996 г. перед Лицзянским землетрясением, с 1996 г. после Лицзянского землетрясения по 2001 г. перед Куньлунским землетрясением, с 2001 г. после Куньлунского землетрясения до 2008 г. перед Вэньчуаньским землетрясением.

compressive stress axes have changed to be NE-SW oriented after the 2001 Kunlun earthquake. The stress state of the Shanxi tectonic belt is primarily recorded as the alternating distribution of horizontal shear and horizontal extension. The locations of the horizontal shear stresses correspond to the N-S oriented segments of the Shanxi tectonic belt, and the locations of the horizontal extensive stresses correspond to the NE-SW oriented segments of the Shanxi tectonic belt.

In order to reveal whether the above stress change before and after the Kunlun earthquake is caused by the regional stress adjustment or by other tectonic activities, we analyze the plunge distribution of stress axes of these different time periods. Figure 5 shows that in the two periods before 2001 Kunlun $M s=8.0$ earthquake, plunges of most stress axes are below $45^{\circ}$, and indicate that the maximum stress axes are mainly low-angle. After the Kunlun earthquake when orientations of maximum stress axes turn to be NE-SW oriented, the majority of the stress data (122 points) still indicates that the plunges of the maximum stress axes are low-angle, while the minority data (47 points) indicate high angles. From these minority data, it can be noted that the locations lie in the NE-SW oriented basin or in the transition area from $\mathrm{N}-\mathrm{S}$ oriented tectonic structures to the NE-SW oriented basin. There are grounds to conclude that in this period, the regional NE-SW stress orientation is active in the Shanxi belt, the N-S oriented tectonic structures of the Shanxi belt are subject to hori- 

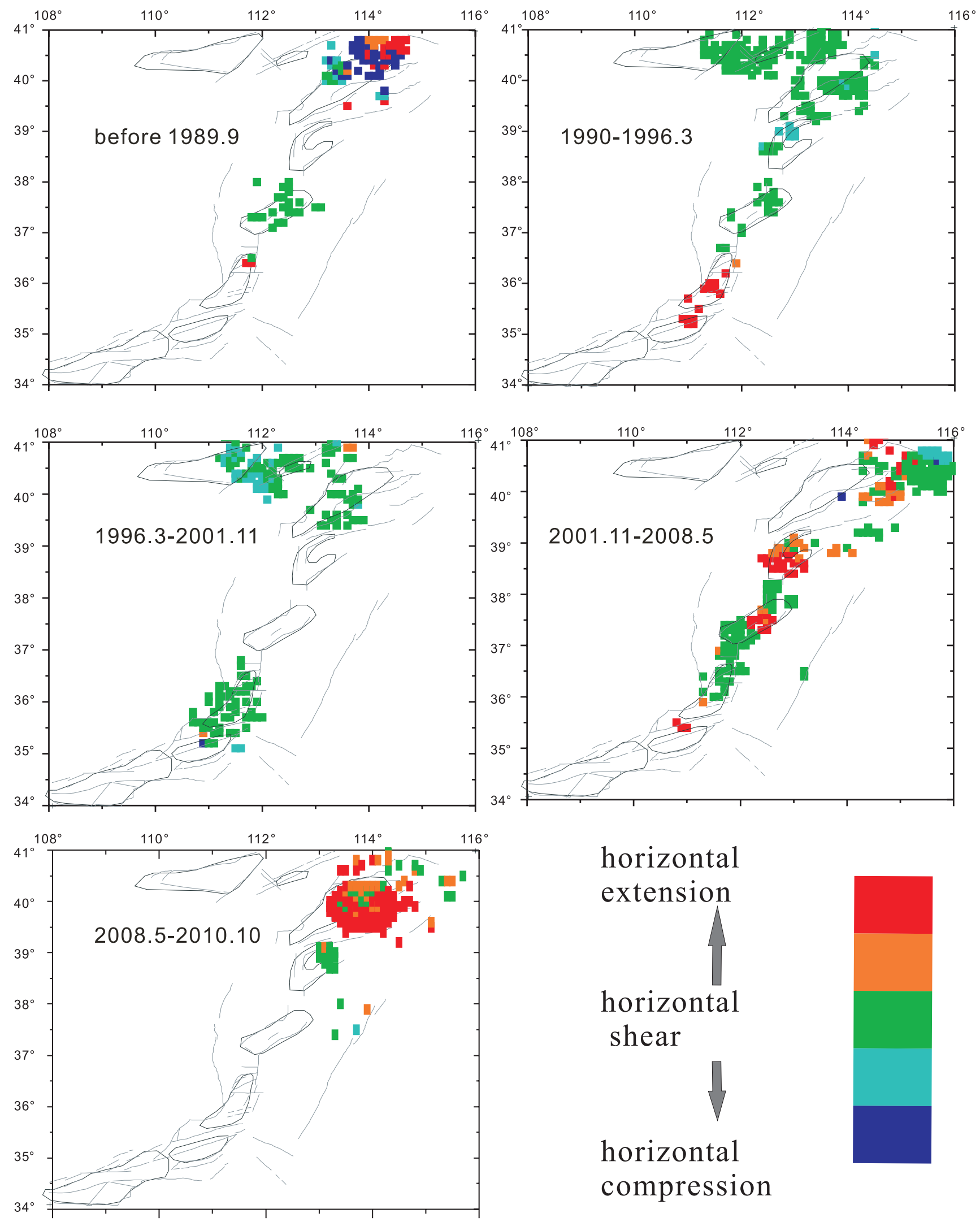

Fig. 4. Distribution of the stress state of the Shanxi tectonic belt in different periods of time: from 1967 to September 1989 , from 1990 to 1996 before the Lijiang earthquake, from 1996 after the Lijiang earthquake to 2001 before the Kunlun earthquake, from 2001 after the Kunlun earthquake to 2008 before the Wenchuan earthquake, and from 2008 after the Wenchuan earthquake to 2010.

Рис. 4. Напряженное состояние тектонического пояса Шаньси в следующие временные периоды: с 1967 г. по сентябрь 1989 г. , с 1990 г. по 1996 г. перед Лицзянским землетрясением, с 1996 г. после Лицзянского землетрясения по 2001 г. перед Куньлунским землетрясением, с 2001 г. после Куньлунского землетрясения до 2008 г. перед Вэньчуаньским землетрясением и с 2008 г. после Вэньчуаньского землетрясения по 2010 г. 

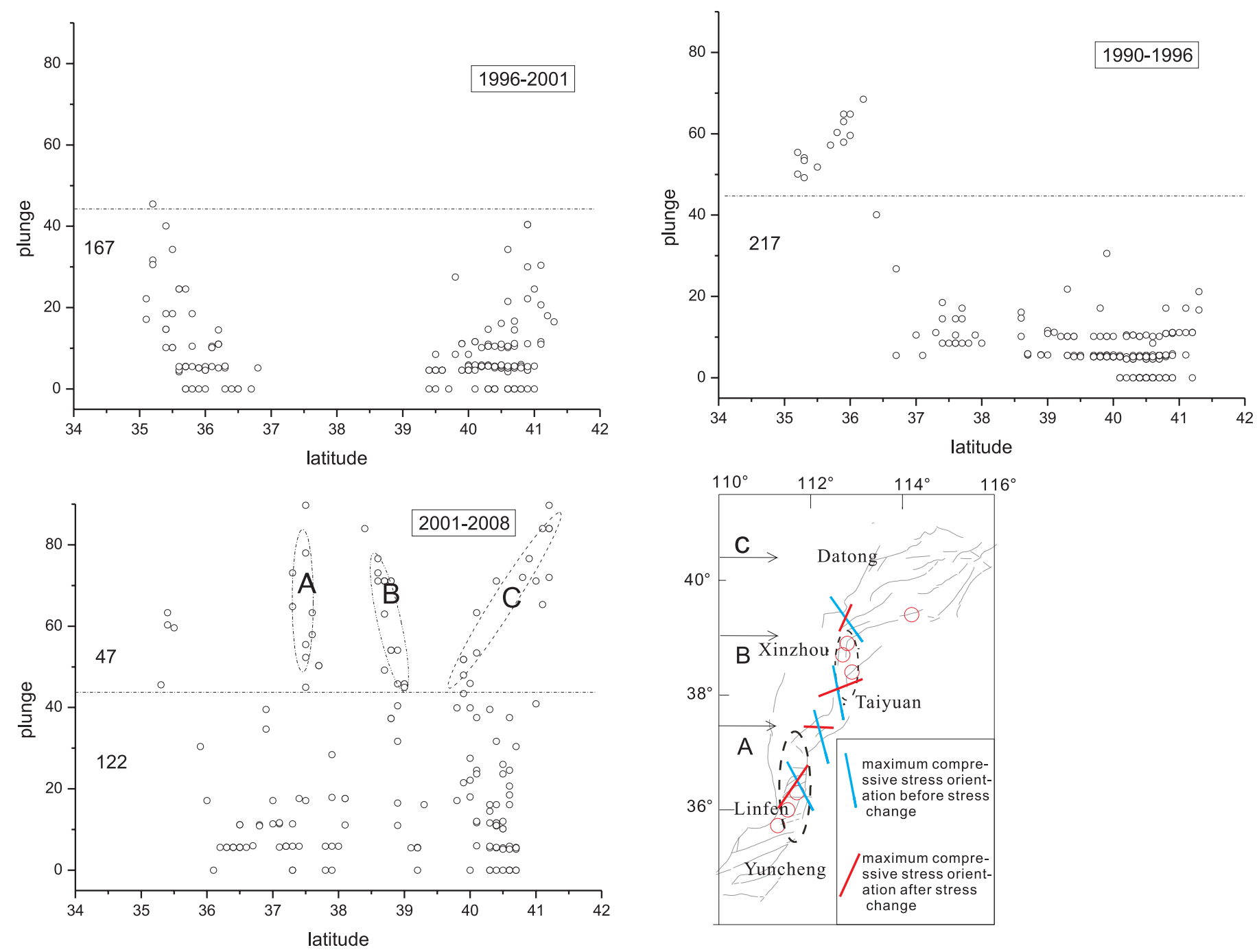

Fig. 5. Plunge distribution of stress axes versus latitudes in the Shanxi tectonic belt (A, B and C represent the relatively centralized areas of the high-angle maximum compressive stress axes).

Рис. 5. Распределение погружения осей напряжений относительно широтных координат тектонического пояса Шаньси (А, В и С представляют участки относительной концентрации осей максимальных напряжений сжатия с крутым углом падения).

zontal shear, and the NE-SW oriented basin is subject to extension. It can thus be suggested that the stress change of the Shanxi belt is caused by adjustment of the regional stress field, rather than diverse seismic activities.

\section{CONCLUSION}

We found that orientations of the principal compressive stress axes are changing with time. In these periods, for which the data distributions are analyzed, the orientations of the maximum principal compressive stress axes have turned from mainly NW-SE before the 2001 Kunlun earthquake to the NE-SW after the earthquake.

It is shown that the majority of the historical strong earthquakes in the Shanxi tectonic belt occurred in the locations of the nearly $\mathrm{N}-\mathrm{S}$ oriented segments, which dem- onstrates the controlling effect of N-S oriented segments on the occurrence of the strong earthquakes on this region. The stress inversion results show that when the maximum principal compressive stress axes are mainly NE-SW oriented, the stress state of the Shanxi tectonic belt is primarily recorded as an alternating distribution of horizontal shear and horizontal extension. The locations of the horizontal shear stress state correspond to the $\mathrm{N}-\mathrm{S}$ oriented segments of the Shanxi tectonic belt, and the locations of the horizontal extensive stress state correspond to the NESW oriented segments of the belt. We can explain these characteristics through a simple tectonic model - when the Shanxi tectonic belt is compressed in the NE-SW direction, dextral shear deformation occurs in the $\mathrm{N}-\mathrm{S}$ oriented segments of the belt, which facilitates seismic activities. Under this tectonic impact, extension occurs in the NESW oriented tectonic segments. We suppose that the 
strong earthquakes in the Shanxi belt are related to the regional NE-SW oriented tectonic stress.

\section{ACKNOWLEDGEMENT}

We thank Prof. Yuri L. Rebetsky who let us use his program for stress inversion. We are grateful to Wali Jiang for communicating and offering her study results about the Shanxi tectonic belt. This research was supported by NSFC Grant 41172180, the Basic Research Funds from the Institute of Geology, China Earthquake Administration (Grant IGCEA1204) and the Russian Fund for Basic Research (Grant 12-05-91161-GFEN-a).

\section{REFERENCES}

Chen X.B., Zang S.X., Liu Y.G. et al., 2005. Horizontal movement of Ordos block and the interaction of Ordos block and adjacent blocks. Journal of the Graduate School of the Chinese Academy of Sciences 22 (3), 309-314 (in Chinese).

Deng Q.D., Cheng S.P., Min W. et al., 1999. Discussion on the Cenozoic tectonics and dynamics of Ordos block. Journal of Geology Mechanic 5 (3), 13-21 (in Chinese).

Fan J.X., Ma J., Gan W.J., 2003. Movement of Ordos block and alternation of activity along its boundary. Science in China Series D: Earth Sciences 46 (2), 168-180. http://dx.doi.org/10.1360/03dz0013.

Hu H.M., 1988. Regional strain field: Contemporary movement property of the active fault system around Ordos massif. In: Research Group on Active Fault System around Ordos Massif of State Seismological Bureau. Active Fault System around Ordos Massif. Seismological Press, Beijing, 174-182 (in Chinese).

Ma X.Y., 1989. The state of recent crustal stress. The Lithospheric Dynamics Atlas of China. 20 p. (in Chinese).

Rebetsky Yu.L., 1999. Methods for reconstructing tectonic stresses and seismotectonic deformations based on the modern theory of plasticity. Doklady Earth Sciences 365A (3), 370-373.

Rebetsky Yu.L., 2003. Development of the method of cataclastic analysis of shear fractures for tectonic stress estimation. Doklady Earth Sciences 388 (1), 72-76.

Shao H.C., Su G., 1999. Analysis on the seismicity trend around the Ordos block. Northwestern Seismological Journal 21 (4), 119-128 (in Chinese).

Su G., 1984. Research on regional seismicity with active block as compartment, Seismicity of Ordos block. Northwestern Seismological Journal 6 (2), 1-10 (in Chinese).

Xu X.W., Chen G.L., Ma X.Y. et al., 1994. Rotation and dynamics of blocks in North China and its adjacent areas. Earth Science - Journal of China University of Geosciences 19 (2), 129-138 (in Chinese).

Zhang X., Jiang Z.S., Zang X.L., 2002. Aseismic negative dislocation inversion of recent horizontal crust movement in North China. Journal of Geodesy and Geodynamics 22 (3), 40-45 (in Chinese).

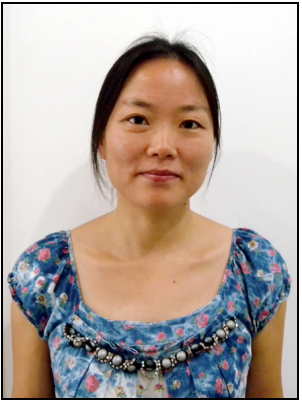

Wang Kaiying, Ph.D, Candidate of Tectonic Geology and Tectonophysics

State Key Laboratory of Earthquake Dynamics, Institute of Geology, China Earthquake Administration

Beijing 100029, China

凶 e-mail: love.zyx@hotmail.com

Ван Кайюин, доктор наук (геотектоника, тектонофизика)

Государственная центральная лаборатория геодинамики Земли, Институт геологии,

Администрация по землетрясениям Китая

100029, Пекин, Китай

\e-mail: love.zyx@hotmail.com 


\section{K. Wang et al.: Present-day stress state of the Shanxi tectonic belt}

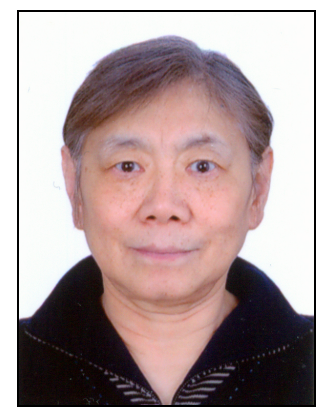

Ma Jin, academician of Chinese Academy of Sciences, Geologist and Tectonophysicist

State Key Laboratory of Earthquake Dynamics, Institute of Geology, China Earthquake Administration Beijing 100029, China

e-mail: dzjmajin@gmail.com

Ма Дзинь, академик Китайской Академии наук, геолог, тектонофизик

Государственная центральная лаборатория геодинамики Земли, Институт геологии,

Администрация по землетрясениям Китая

100029, Пекин, Китай

e-mail: dzjmajin@gmail.com

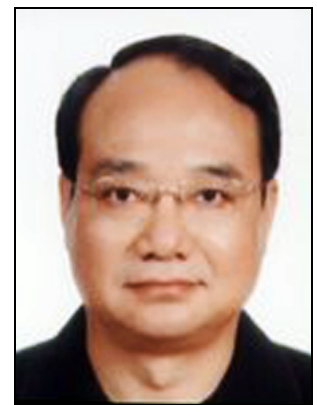

Diao Guiling, Senior Researcher, Geophysicist

Earthquake Administration of Hebei Province

Shijiazhuang 050012, China

e-mail:dgl@eq-he.ac.cn

Дао Джилин, старший научный сотрудник, геофизик

Администрация по землетрясениям провинции Хэбэй

050012, Шицзячжуан, Китай

e-mail: dgl@eq-he.ac.cn 